\title{
Desembaralhando: a mobile application for intervention in the problem of dyslexic children mirror writing
}

Luciana Cidrim ${ }^{(1)}$

Pedro Henrique Magalhães Braga ${ }^{(1)}$

Francisco Madeiro(1)

(1) Universidade Católica de Pernambuco, Recife, PE, Brasil.

Research support source: Coordenação de Aperfeiçoamento de Pessoal de Nível Superior (CAPES).

Conflict of interest: Nonexistent

\section{(c) (i)}

Received on: July 27, 2017

Accepted on: December 8, 2017

Mailing address:

Luciana Cidrim Calado Meira

Rua Carlos Pereira Falcão, 298 - Boa

Viagem

CEP: 51021-320 - Recife, Pernambuco, Brasil

E-mail: lucianacidrim@terra.com.br

\section{ABSTRACT}

Purpose: to present a new application for mobile devices, referred to as Desembaralhando, for intervention in the problem of dyslexic children mirror writring.

Methods: the development of the application is the result of a set of clinical and speech therapy information and experiences, which points out frequency of letter mirroring as a challenging problem in children with dyslexia. The application, developed in the light of the multisensory approach, was created by a multidisciplinary team of computer scientists, a game designer and a speech therapist, in order to meet users requirements, such as appropriate fonts and colors.

Results: the activities stimulate phonological awareness skills from the association between images and words, audio aids, as well as an original function that is the rotational movement of letters $b / d$ and $a / e$, which facilitates the perception of the visual layout of the letters.

Conclusions: guidelines such as the choice of typography and interface colors appropriate to dyslexic children are used to favor intervention, in order to minimize the difficulties of these children regarding letters mirroring.

Keywords: Speech, Language and Hearing Sciences; Dyslexia; Reading; Handwriting; Technology 


\section{INTRODUCTION}

Reading and writing are essential skills for the individuals cultural development, providing their insertion in most social environments ${ }^{1,2}$. Reading and writing are important not only for school learning, but also for life outside school. Failures in reading and writing acquisition and development tend to cause disinterest, poor performance, and often school dropout $^{2}$.

Learning to read and write, especially in the early grades of elementary school, is a relevant skill in the child development process, and can be a challenge for many children. In this context, one of the aspects that draw attention concerns the spelling, that is, the conventional writing mastery of words ${ }^{3}$.

Learning to write presupposes the comprehension of a series of properties or aspects of the written language that are part of the orthographic system. This learning encompasses: differentiating the stroke of letters, knowing what sounds correspond to letters, identifying the position of the letter within the word, understanding that the same letter can represent various sounds, just as the same sound can be represented by several letters ${ }^{4}$.

Once a specific disorder of reading and/or writing learning has been diagnosed, the search for appropriate intervention programs becomes a challenge for professionals who work directly with these children ${ }^{47}$.

Helping children with learning difficulties has been a major concern of educational practice ${ }^{6,8,9}$. The use of technological tools helps the intervention of children with learning disorders ${ }^{10-15}$. Recent developments use Information and Communication Technologies (ICT) applications to support the learning needs of children with reading and writing difficulties ${ }^{10-12}$.

Dyslexia, in turn, is a specific language disorder of constitutional origin, characterized by difficulties in the decoding of isolated words, due to an inefficiency in the processing of phonological information ${ }^{16}$. The essential characteristic of dyslexia is the specific and significant impairment of the development of reading skills, not attributable to other causes such as mental deficiency, sensory disorders or inadequate schooling ${ }^{17}$.

Phonological processing skills are considered a prerequisite for acquiring writing, as well as reading and writing skills, leading to the development of more elaborate levels of phonological processing in a reciprocal causal relationship ${ }^{18-20}$.

The specific writing disorder, also known as dysorthographia, is a change in the written language planification, which causes difficulties in learning the spelling, grammar and writing, although the intellectual potential and level of education are suitable for their age ${ }^{17}$.

Some errors in the process of acquiring written language, despite showing signs of a possible dysortography, may be part of the process of appropriation of the orthographic system of the language and be overcome during schooling. In the case of children with dysortography resulting from the learning disorder, these characteristics do not disappear with the progression of schooling, and are persistent ${ }^{21-23}$.

The inversions of letters can be characterized by two types of occurrences, the first being the actual mirroring, or rotations, in which the letters are rotated relative to their own axis, such as the inversions of $d$ and $b, q$ and $p, a$ and $e$. Similarly, one can consider the occurrence of changes in the position of the letters within the words as inversion, for example, in the situation in which "estante" is written as "setante", the letters " $\mathrm{e}$ " and " $\mathrm{s}$ " had their positions reversed" ${ }^{21}$. The stage of mirroring letters may also be transitory, and is a common manifestation in the first year of literacy ${ }^{24-27}$.

The child takes the first seven years of life to understand principles of invariance that apply to notions of object, quantity, number, space, and time ${ }^{21}$. With these notions, the child may be able to recognize an object independent of some circumstances, as shown in Figure 1. In this example, even changing position, the object does not lose its characteristics, remaining a doll. 


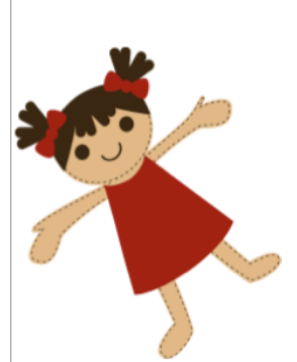

(a)

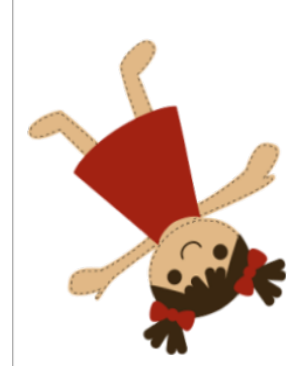

(b)

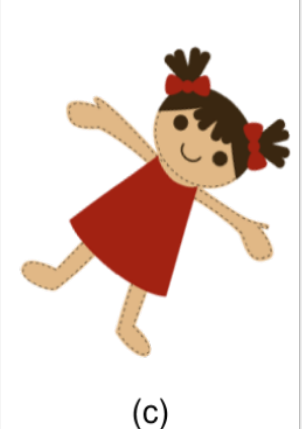

(c)

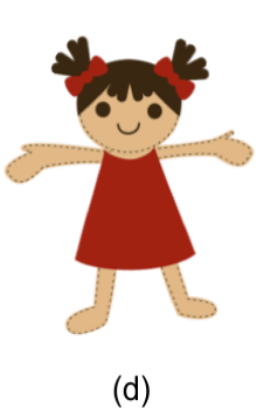

(d)

Figure 1. Doll object image to explain the notion of invariance of Piaget (adapted from the model proposed by Zorzi ${ }^{21}$ )

Differences related to orientational aspects, specifically mirroring $(b, d)$, rather than rotation $(b, q)$, are more difficult for children to learn during the writing process $^{25}$. In the case of letters and/or numerals, the position changes modify their sound properties, as shown in Figures 2 and 3.

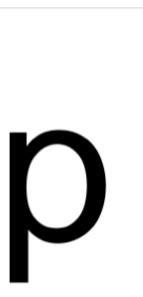

(a)

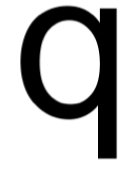

(b)

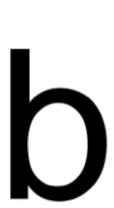

(c)

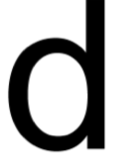

(d)

Figure 2. Image of the letter $p$ in different positions (adapted from the model proposed by Zorzi ${ }^{21}$ )

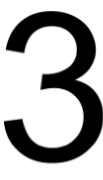

(a)

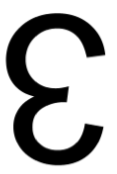

(b)

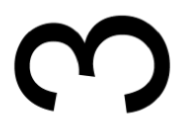

(c)

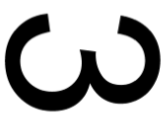

(d)

Figure 3. Image of number 3 in different positions (adapted from the model proposed by Zorzi²1)

For too long and insistently we have been led to see, in the mistakes children make in writing, signs of disorders and pathologies. The mirroring of letters is a typical example in this way, even partial and distorted, of understanding what learning is ${ }^{21}$. In this sense, this article presents an application developed for mobile devices, called Desembaralhando, which assists the intervention in the problem of letter mirroring by dyslexic children.

\section{METHODS}

This study contemplates the development of an application. It did not require approval by the Ethics Committee because it did not involve human research.

The Desembaralhando mobile application was developed with the purpose of assisting the intervention of dyslexic children in the context of the problem of letter mirroring or inversions, considering that in these subjects the problem persists for a longer time than 
expected in the process of learning to read and write. It is intended for children in the age group of 7 to 10 years old, considering that at the age of 7 early intervention in children with signs of specific difficulties in school learning can minimize academic losses ${ }^{8}$.

The application can be used by speech therapists, educators and professionals involved in the multidisciplinary team who work in the rehabilitation of dyslexic children, and may be useful for parents to stimulate ludic activities at home. It is an intuitive tool so that, even without the help of an adult, the child will have ease of use.

This is an application for the Android platform, with its first version developed for smartphones.

In the process of building the application, the team, comprised of computer scientists, designer and speech therapist, conducted a search on the GooglePlay and AppStore application stores using the words 'dyslexia' and 'dislexia' to identify applications with a similar proposal to Desembaralhando. It is important to emphasize that this search served only as a query, since the conception of the idea and all the operation of the application described here were not based on any technological tool consultation. A small number of applications available for the Portuguese language that contemplate the specific work with dyslexic children were observed. In a national survey ${ }^{15}$, the shortage of articles published in Brazil on ICT and dyslexia was found when compared to international research.

The Desembaralhando application presents an interface with clear, light colors, featuring a unique image content created by a designer. The colors used in the application interface are light, in shades of blue and yellow, serving two purposes. The first is the ergonomic one, given the difficulty of dyslexics in distinguishing forms in environments with a lot of visual stimuli, or in a completely white background ${ }^{12}$. The second is the contrast of the background of the screen with the colors of the figures presented in the application, which highlights the figures.

Desembaralhando has recording and playback capabilities of audio content in order to assist the child in recognizing the words available in the activities. Due to the lack of phonological awareness, dyslexics need auditory cues that favor access to the mental lexicon of words $^{19,20}$.

For the creation of the application interface, a typography specific for dyslexics, OpenDyslexic, was used. This source was proposed by Alberto Gonzalez ${ }^{28}$ in order to minimize the most frequent difficulties of reading of the dyslexic, as the exchanges of letters with similar formats or letters that are images mirrored of each other.

Regarding the operation of the Desembaralhando application, three screens are highlighted: a) the initial screen to select the pair of letters to be worked on (b/d and $\mathrm{a} / \mathrm{e}$ ) or the sentence module (Figure 4); b) the interaction screen with the activities to work on the problem of letter mirroring by means of isolated words from the selection of the pair of letters (Figure 5) and c) the screen of the phrases module (Figure 7).

The choice of the pairs of letters $d / b$ and $a / e$ and, consequently, of the words used, was due to the fact that it is presented in the literature that the inversions of the letters are common both in the process of appropriation of reading and writing as for being part of a set of specific difficulties observed in dyslexics ${ }^{21,24,27}$.

\section{RESULTS}

Figure 4 shows the application home screen image, where the user chooses to work with the pair of letters, $\mathrm{a} / \mathrm{e}$ or $\mathrm{b} / \mathrm{d}$, as well as the phrases module. It is observed that the letter $\mathrm{d}$, of the name desembaralhando, is in the form of a spiral, which refers to the unfolding, unscrambling, as well as it also symbolizes the evolution of the child. The chosen background is formed by several colored cubes, that can be associated to play and to docking games. This background is used as background in the application screens.

After selecting the activity to be worked on, the child will have access to the screen with the chosen image, and the word will already appear written, as shown in Figure 5. We have chosen to show the written word because the main objective of this activity is to provide conditions for the child to recognize the difference in the stroke of letters. In addition, children with marked difficulties in the mirroring of letters present a greater chance of not hitting the correct way of writing the words, and may become disaffected with the activity.

The visual elements found in Figure 5 are: (a) correctness checking mechanism of the written word; (b) image of the object representing the word written on the screen; (c) button that plays an audio with the pronunciation of the word written on the screen, working as a hint for the user; (d) the word represented by the figure that must be written correctly; (e) the letter that can be rotated; (f) area of the application that allows you to rotate the highlighted letter, (g) button that activates the voice recording feature. 
One of the features of the application is the possibility of rotation of letters representing mirrored images of each other, for example, b/d, as shown in Figure 6. The letter rotation process is intended to create a way to differentiate between the letters, highlighting the details of its format. The child will also be able to listen to a hint of the word, which is accessible through a button in the lower left corner of the image associated with the word. This hint represents the pronunciation of the word being worked on.

As shown in Figure 5, there is an icon, identified with (a), with which the child can check whether the word is spelled correctly. If correct, a sound indicating the hit will be played and an animation is performed on the word, highlighting and drawing attention to the correct writing. In addition, the gray icon, which represents a default state, is assumed to be green, indicating that the word is spelled correctly. If the child makes an error, only a sound indicating that the word is not correct is reproduced. There is no count of errors, nor limit of attempts. The child is free to try as many times as he/she wants.

Another activity available in the application is that of sentence structure (Figure 7). Initially, the words are scrambled, and the child's goal is to put them in order. The purpose of this activity is to give the child a greater time of contact with the words worked on, having the support of the images to associate with the written word, making the activity playful.

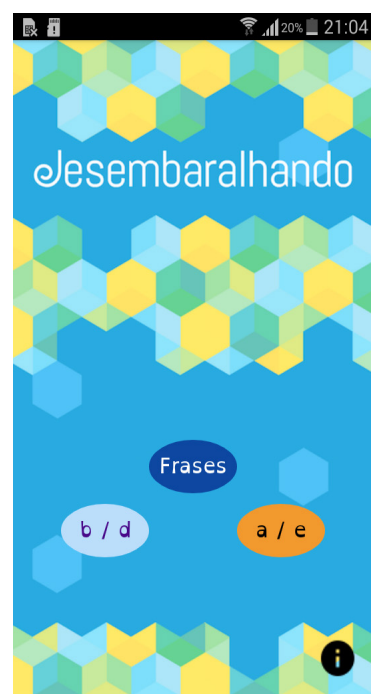

Figure 4. Application home screen

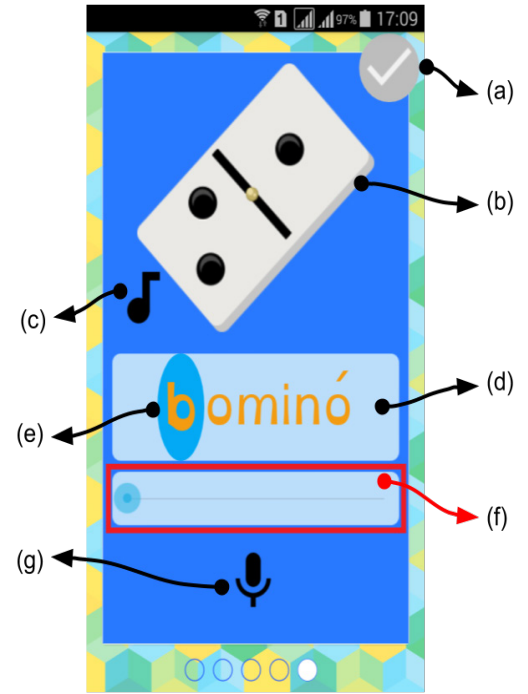

Figure 5. Screen of the chosen word
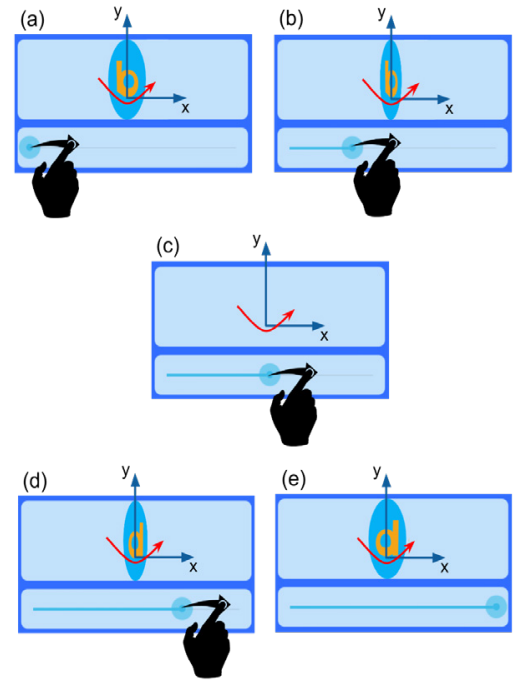

Figure 6. Rotation of the letter $b$

四娄 窟 $463 \%-21: 48$

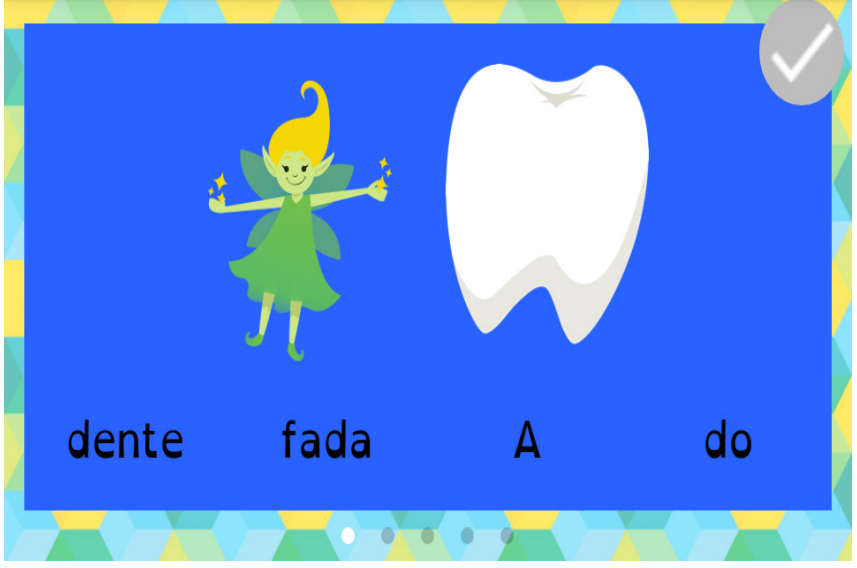

Figure 7. Phrase module screen 


\section{DISCUSSION}

For children with dyslexia, only traditional forms of teaching models are not sufficient to achieve more adequate learning conditions ${ }^{29}$. Dyslexics need other teaching mechanisms based on multisensory strategies, that is, through the relationships between images and sounds. ICT is one such strategy ${ }^{10,12,30}$. One of the benefits of using technology tools for education is to increase involvement and motivation to learn ${ }^{11,29}$. The use of ICT helps children learn to read and write in fun ways. Smartphones and tablets can be very useful for children with learning difficulties, especially children with dyslexia ${ }^{29,30}$.

This article presents an original tool whose purpose is to help dyslexic children in the face of the problem of mirror writing.

This section describes eight applications designed for Android or iOS systems for children with learning disabilities in reading and/or writing, especially dyslexia. Applications were taken from Google Play and the App Store virtual stores, using the search with the terms dyslexia and dislexia.

In general, in the evaluated applications, there is a strong tendency to propose activities that favor the learning of reading and writing, without delimiting a specific problem and/or difficulty to be worked on. In addition, although the difficulties faced by dyslexic children are difficult to overcome, no investment is observed in the construction of tools specifically designed for this public.

Alphabetics $^{31}$ is an application that features activities to teach the format and sound of each letter of the alphabet with the help of the audio feature. The proposal of the activities of this application is based on the multisensorial approach, used to learn the phonemes. On Desembaralhando, the available audio resource was recorded by the speech therapist, a member of the team, who sought to perform a pronunciation as natural as possible so as not to generate discomfort to the user. It is important to note that many audio-enabled applications use text-to-speech conversion programs, which commonly generate a voice that sounds as synthetic, unnatural, when it comes to Portuguese.

Hairry Letters ${ }^{32}$ is the first of a series of applications that aim to introduce the learning of frequent words in the English language, called "sight words". The function of Hairry Letters is to teach the alphabet, highlighting the sounds of each letter, as well as their formats. In this application, there is the option for the child to perform the motor training of writing letters and words. Although Hairry Letters ${ }^{32}$ has activities aimed at learning the shape of letters, there is no special attention to letters with similar strokes, such as $p$ and b. Desembaralhando, in turn, gives special attention to the intervention in the scope of the problem of letter mirroring.

Dyseggxia ${ }^{33}$, as well as Desembaralhando, is an application that has an interface with light colors, and clear and playful appearance. Although the clear appearance is a common feature of both applications, Dyseggxia has a more childlike interface. Dyseggxia is an application with a fixed word repertoire, that is, the user cannot insert new words. The words available in this application were selected from specific errors committed by children with reading and writing disorders.

Arqueiro Defensor ${ }^{34}$ presents the proposal to work on phonological awareness of letters with similar traces, especially $n$ and $u$, as well as, $m$ and $w$, but does not propose in its activities the letter rotation tool, as was created on Desembaralhando.

Lee paso a paso ${ }^{35}$, Palabras especiales ${ }^{36}$ and Mimosa e o reino das $\operatorname{cores}^{37}$, as well as Desembaralhando, were created to work with dyslexic children through multisensory strategies. The activities presented in these applications associate letters with sounds, and words with pictures. On Lee paso a paso, there is an interesting activity, which is to count the syllables, which values the notion of the structure of words. On Mimosa e o reino das $\operatorname{cores}^{37}$, words are also related to images by means of a memory game activity. On Desembaralhando, the activity of forming sentences, from words and images, aims to increase the frequency of use of words that children with dyslexia have more difficulty writing.

On Aramumo ${ }^{38}$, the child should hear a set of words and then move the syllables that are in the floating bubbles towards a grid to form the correct word. As with Desembaralhando, the touchscreen feature makes it easy for the user to interact through touch. On Desembaralhando, the ability to rotate the letters $p$ and $b$ is a useful tool for the child to recognize the visual difference of the letters.

\section{CONCLUSION}

Desembaralhando is a mobile application for support in the intervention of dyslexic children. We opted for activities that contemplate the problem of mirroring or inversions of letters, especially the pairs of letters $a / e$ and $b / d$, which are observed in the process 
of appropriation of the written language of these subjects. Through easy-to-interact screens and a fun interface, this application seeks to attract the children interest without proposing activities that account for their mistakes, but rather that they can learn through their own attempts. In its implementation, the technological feature of rotating the letters in their own axes is emphasized in order to facilitate the recognition of the correct spelling, association with the image that represents the word, as well as the audio feature which facilitates the recognition of the sound properties of each letter.

As future work, it is intended to expand the use of this application for tablets, evaluate and validate the application by performing interventions with target subjects, develop a system of registration of user accounts to monitor their progress in the application and insert new words that present high frequency in the writing of the Brazilian Portuguese language.

\section{ACKNOWLEDGEMENT}

To Coordenação de Aperfeiçoamento de Pessoal de Nível Superior (CAPES) for granting the first author the financial support.

\section{REFERENCES}

1. Cunha VLO, Capellini SA. Construction and validation of an instrument to assess the reading comprehension of students from the third to the fifth grades of elementary school. CoDas. 2014;26(1):28-37.

2. Zorzi JL, Ciasca S. Caracterização dos erros ortográficos em crianças com transtornos de aprendizagem. Rev. CEFAC. 2008;10(3):321-31.

3. Dias BS, Ávila CRB. Uso e conhecimento ortográfico no transtorno específico de leitura. Rev Soc Bras Fonoaudiol. 2008;13(4):381-90.

4. Capellini SA, Romero ACL, Batista AO, Sampaio MN, Fusco N, Cervera-Mérida JF et al. Spelling performance of students of 2nd to 5th grade from private teaching . Rev. CEFAC. 2012;14(2):254-67.

5. Oliveira AM, Capelinni SA. Word database for senior high school reading: E-READING III. Rev. CEFAC. 2016;18(6):1404-46.

6. Alves D, Casella E, Ferraro A. Spelling performance of students with developmental dyslexia and with developmental dyslexia associated to attention deficit disorder and hyperactivity. CoDAS. 2016;28(2):123-31.
7. Bermejo VS, Escribano CL. Nuevos aportes a la intervención en las dificuldades de lectura. Univ Psychol. 2005;4(11):13-22.

8. Bigozzi L, Christian T, Pinto G, Gamannossi BA. Predicting dyslexia in a transparent orthography from grade 1 literacy skills: a prospective Cohort study. Read Writ Q. 2016;32(1):353-72.

9. Kawano CE, Kida ASB, Carvalho CAF, Ávila CRB. Parâmetros de fluência e tipos de erros na leitura de escolares com indicação de dificuldades para ler e escrever. Rev Soc Bras Fonoaudiol. 2011;16(1):9-18.

10. Skiada R, Soroniati E, Gardeli A, Zissis D. EasyLexia: A mobile application for children with learning difficulties. Proc Comp Scien. 2014;27:2(2)18-228.

11. Borhan N, Sharbini $H$, Chan $P$, Julaihi $A$. Developing reading skills using sight word reading strategy through interactive mobile game-based learning for dyslexic children. Int J Innov Educ Res. 2015;3(10):1-10.

12. Zikl P, Bartosova IK, Viskosa KJ, Havlickova K, Kucirkova J, Zetkova B. The Possibilities of ICT use for compensation of difficulties with reading in pupils with dyslexia. Proc Soc Behav Scien. 2015;176(1):915-22.

13. Cidrim L, Cajueiro LE, Braga PHM, Bezerra R, Gama C, Madeiro F. Dis-Ortografando: um aplicativo desenvolvido para auxiliar a intervenção com crianças disléxicas. In: Cidrim L, Costa S. (Orgs.). Tecnologias da Informação e da Comunicação (TIC) Aplicadas às Ciências da Linguagem. Curitiba: CRV. 2015. p. 9-22.

14. Schneps MH, Thomson CC, Sonnert G, Pomplun M. E-readers are more effective than paper for some with dyslexia. PLOS One. 2013;8(9):1-9.

15. Cidrim L, Madeiro F. Information and Communication Technology (ICT) applied to dyslexia: literature review. Rev. CEFAC. 2017;19(1):99-108.

16. Lyon GR, Shaywitz S, Shaywitz BA. Defining dyslexia, comorbidity, teacher's knowledge of language and reading. Ann of Dyslexia. 2003;3(1):1-12.

17. Mousinho R, Navas AL. Mudanças apontadas no DSM-5 em relação aos transtornos específicos de aprendizagem em leitura e escrita. Rev Deb Psiq. 2016;6(3):38-45.

18. Arduini RG, Capellini SA, Ciasca SM. Comparative study of the neuropsychological and neuroimaging 
evaluations in children with dyslexia. Arq. Neuropsiquiatr. 2006;64(2B):2006.

19. McArthur G, Castles A, Kohnen S, Larsen L, Jones $\mathrm{K}$, Anandakumar $\mathrm{T}$ et al. Sight word and phonics training in children with dyslexia. J Learn Dis. 2013;48(4):391-407.

20. McArthur G, Kohnen S, Jones K, Eve P, Banales E, Larsen $L$ et al. Replicability of sight word training and phonics training in poor readers: a randomized controlled trial. PeerJ. 2015;3(1):2-21.

21. Zorzi JL. Aprendizagem e distúrbios da linguagem escrita: Questões clínicas e educacionais. Porto Alegre: Artmed, 2003.

22. Galaburda A, Cestinick L. Dislexia del desarollo. Rev Neurol. 2003;36(1):3-9.

23. Cervéra-Mérida JF, Ygual-Fernández AA. Una propuesta de intervención em trastornos disortográficos atendiendo a la semiologia de los errores. Rev Neurol. 2006;42(1):117-26.

24. Garcia TM. Reconhecimento das letras: considerações sobre espelhamento e variação topológica em fase inicial de aprendizagem da leitura. Let Hoje. 2013;48(1):12-20.

25. Gottfried JA, Sancar F, Chatterjee A. Acquired mirror writing and reading: evidence for reflected graphemic representations. Neurophsychologia. 2003;41(1):96-107.

26. Blackburne LK, Eddy MD, Kalra P, Yee D, Sinha P, Gabrieli JDE. Neural correlates of letter reversal in chidren and adults. PLOS One. 2014;9(5):1-15.

27. Roberto TMG. Reconhecimento das letras: considerações sobre espelhamento e variação topológica em fase inicial de aprendizagem da leitura. Let Hoje. 2003;48(1):12-20.

28. Opendyslexic. [Acesso em: 21 Mai. 2017]. Disponível em: http://opendyslexic.org/about/.

29. Léon AM, Bravo CB, Fernández AR. Review of Android and iOS tablet apps in Spanish to improve reading and writing skills of children with dyslexia. Procedia Soc Behav Sci. 2017;237(1);1383-9.

30. Berninger VW, William N, Tanimoto $S$, Thompson $\mathrm{R}$, Abbott RD. Computer instruction in handwriting, spelling, and composing for students with specific learning disabilities in grades 4-9. Comput Educ. 2015;81(1):154-68.

31. Alphabetics. [Acesso em: 9 Jun. 2017]. Disponível em: https://itunes.apple.com/br/app/alphabetics/ id621297604? $\mathrm{mt}=8$ alphabetics.
32. Hairry Letters. [Acesso em: 9 Jun. 2017]. Disponível em: https://itunes.apple.com/br/app/hairy-letters/ id997423057? $\mathrm{mt}=8$.

33. Dyseggxia. [Acesso em: 21 Jun. 2017]. Disponível em: http://dyslexiahelp.umich.edu/tools/apps.

34. Arqueiro Defensor. [Acesso em: 9 Jun. 2017]. Disponível em: https://play.google. com/store/apps/details?id=com.itabits. CamillaLagPomba\&hl=pt_BR.

35. Lee Paso a Paso. [Acesso em: 11 Jun. 2017]. Disponível em: https://itunes.apple.com/us/app/ lee-paso-a-paso-learn-to-read-spanish-stepby-step/id550555462? $\mathrm{mt}=8$ lee.

36. Palabras especiales. [Acesso em: 4 Jun. 2017]. Disponível em: https://itunes.apple.com/gt/app/ palabras-especiales/id451723454? $\mathrm{mt}=8$.

37. Mimosa e o reino das cores. [Acesso em: 9 Jun 2017]. Disponível em: https://play.google. com/store/apps/details?id=com.itabits. colorrindo\&hl=pt_BR.

38. Aramumo. [Acesso em: 2 Jun. 2017]. Disponível em: https://www.reab.me/aramumo-aplicativopara-disturbio-de-aprendizagem/. 